\title{
Efektifitas Pengelolaan Lokasi Wisata Curug dan Bukit di Subang Jawa Barat
}

\author{
Alfiah $^{1}$ Jeni Andriani ${ }^{2}$ Anah Furyanah ${ }^{3}$ \\ Universitas Pamulang \\ Alfiah675@gmail.com Dosen00436@gmail.ac.id dosen01816@gmail.ac.id ${ }^{3}$
}

\begin{abstract}
Tujuan Penelitian ini untuk menemukan, mendeskripsikan, dan menganalisis mengenai regulasi atau komitmen dalam pengelolaan wisata, mengetahui dan menganalisa kemampuan SDM lokal dalam mengeloa lokasi wisata, untuk menemukan, mendeskripsikan, dan menganalisis upaya yang akan dilakukan dalam mengelola potensi wisata di lokasi wisata dan untuk menemukan, mendeskripsikan, dan menganalisis mengenai sarana prasarana yang ada di lokasi wisata. Metode analisis menggunakan metode analisa deskriptif kualitatif dengan strategi fenomenologi. tehnik pengumpulan data melalui kuesioner dan wawancara. Responden dari berbagai pihak yangterlibat, baik aparat desa, pengelola dan pengunjung. Hasil penelitian ini menunjukkan bahwa pengelolaan lokasi wisata belum efektif dapat dilihat sebagai berikut: (1) Saat ini kedua lokasi wisata belum memiliki regulasi baik berupa Peraturan atau Keputusan Kepala Desa sebagai payung hukum/ legalitas pengelolaan lokasi wisata baik Curug Paok maupun Bukit Pasir Jaka, (2) Kemampuan dan pengetahuan SDM local selaku pengelola dalam mengelola lokasi wisata masih sangat terbatas; (3) Pengelolaan Desa Wisata belum ada pencatatan tentang pendapatan dan pengeluaran dari pengelolaan wisata, belum ada pelaporan terkait pengelolaan lokasi wisata, Pengunjung belum dikenakan biaya masuk, (4) Sarana dan prasarana yang belum memadai.
\end{abstract}

\section{Kata Kunci: Efektivitas; Pengelolaan lokasi Wisata}

Abstract. The purpose of this research is to find, describe, and analyze regulations or commitments in tourism management, to know and analyze the ability of local human resources in managing tourist sites and to find, describe, and analyze the efforts that will be made in managing tourism potential at tourist sites and to find, describe, and analyze infrastructure in the tourist sites.

Analytical methods: this study uses descriptive qualitative analysis methods with phenomenological strategies with data collection techniques, namely questionnaires and interviews. Respondents are village apparaturs, tourism managers and visitors. The results of this study indicate that the management of tourist sites has not been effective yet can be seen as follows: (1) At present the two tourist sites do not yet have regulations either in the form of Regulations or Decisions of the Village Head as a legal umbrella / legality for the management of tourist sites both Curug Paok and Bukit Pasir Jaka, (2) The ability and knowledge of local human resources as managers in managing tourist sites is still very limited; (3) Tourism Village Management has not recorded income and expenses from tourism management, there has been no reporting related to the management of tourist sites, visitors have not been charged entry fees, (4) Facilities and infrastructure are inadequate.

\section{Keywords: Effectiveness; Tourism location management}




\section{A. PENDAHULUAN}

Potensi-potensi wisata yang ada di Kabupaten Subang tersebut belum semua terkelola dengan baik atau bahkan ada juga yang belum tergali yang Seperti halnya di Kampung Panyeredan, Desa Cimanggu, Kecamatan Cisalak, Kabupaten Subang Provinsi Jawa Barat yang mempunyai dua potensi wisata yang sangat bagus untuk dikembangkan yaitu wisata Curug Paok dan Bukit Pasir Jaka yang indah untuk dinikmati panoramanya. Potensi wisata bukit pasir Jaka merupakan bukit yang berada disatu hamparan dengan bukit pamoyaman yang masuk desa Kawungluwuk Tanjungsiang, sedangkan Bukit Pasir Jaka terletak di Kampung Panyeredan Desa Cimanggu Kecamatan Cisalak. Bukit Pasir Jaka menawarkan pesona berupa bentangan alam dari ketinggian 1000 mdpl. Bukit Pasir Jaka lokasi tidak terlalu jauh dari pusat kota Kabupaten Subang dapat ditempuh sekitar 1 jam, lokasinya juga tidak terlalu Jauh dari kantor Kepala Desa Cimanggu pengunjung dapat menitipkan kendaran didekat masjid Kampung Panyeredan atau di tempat parkir pengelola wisata yang sekaligus merupakan tokoh adat di kampong penyeradan, atau didepan perumahan penduduk yang memiliki tempat untuk dipakai parker kendaraan. Untuk bisa sampai ke lokasi Bukit Pasir Jaka pengunjung bisa berjalan kaki melewati jalan setapak dengan kontur yang menanjak selama kurang lebih 30-40 menit, jalur ini juga merupakanjalur pendakian ke puncak Gunung Canggah. Lelahnya menuju puncak pasir bukit Jaka akan terbayar setelah pengunjung sampai di lokasi, tawaran pemandangan yang cukup eksotik membayar lebih dari perjalanan mendaki, pengunjung dapat menikmati semburat keemesan langit dipagihari, dan hamparan lautan awan, dimana secara perlajan sanga mentarai akan menampakan diri dari bakik gunung Tanpomas yang sungguh mempesona, sementara hamparan awan putih yang menyelimuti hutan pemukiman yang sangat menakjubkan.

Berdasar kondisi kedua lokasi wisata yang masih apa adanya dan belum dikelola dengan baik, maka peneliti bermaksud untuk melakukan penelitian dengan tujuan untuk mengetahui gambaran tentang efektivitas pengelolaan lokasi wisata baik di curug paok maupun bukit pasir Jaka.

Permasalahan dalam penelitian ini adalah bagaimana bagaimana regulasi/komitmen dalam pengelolaan lokasi wisata? Bagaimana kemampuan SDM Lokal dalam mengelola lokasi wisata ? Bagaimana upaya tata kelola lokasi wisata ? dan bagaimana upaya mengelola sarana prasarana di lokasi wisata ?. Tujuan Penelitian yaitu untuk menemukan, mendeskripsikan, dan menganalisis mengenai regulasi atau komitmen dalam pengelolaan wisata, untuk mnegetahui dan menganalisa kemampuan SDM lokal dalam mengeloa lokasi wisata, untuk menemukan, mendeskripsikan, dan menganalisis upaya yang akan dilakukan dalam mengelola potensi wisata di lokasi wisata dan untuk menemukan, mendeskripsikan, dan menganalisis mengenai sarana prasarana yang ada di lokasi wisata.

\section{B. KAJIAN LITERATUR}

\section{Efektivitas}

Kata efektif berasal dari bahasa Inggris yaitu effective yang berarti berhasil atau sesuatu yang dilakukan berhasil dengan baik. Kamus ilmiah populer mendefinisikan efektivitas sebagai ketepatan penggunaan, hasil guna atau menunjang tujuan. Efektivitas merupakan unsur pokok untuk mencapai tujuan atau sasaran yang telah ditentukan di dalam setiap organisasi, kegiatan ataupun program. Disebut efektif apabila tercapai tujuan ataupun sasaran seperti yang telah ditentukan. Hal ini sesuai dengan pendapat H. Emerson yang dikutip Soewarno Handayaningrat S. (2006:16) yang 
menyatakan bahwa "Efektivitas adalah pengukuran dalam arti tercapainya tujuan yang telah ditentukan sebelumnya.

Lokasi Wisata

Secara umum lokasi wisata dapat diartikan sebagai adalah suatu tempat yang digunakan untuk melakukan kegiatan wisata. Tempat wisata dapat berupa tempat wisata alam dan bangunan. Tempat wisata alam dapat berupa pantai, gunung, dan lainlain, sedangkan tempat wisata bangunan dapat berupa peninggalan sejarah, museum, dan lain-lain. Tempat wisata mengacu pada obyek wisata adalah sebuah tempar rekreasi/tempat wisata, baik berupa alam seperti : gunung, danau. Sungai, panai, lauy atau berupa obyek siwata bangunan seperti museum, benteng, situ peninggalan sejarah dll.(wikipedia).

\section{METODOLOGI PENELITIAN}

Metode analisis menggunakan metode analisa deskriptif kualitatif dengan strategi fenomenologi dengan teknik analisis datanya menggunakan miles dan Huberman dengan tehnik pengumpulan data yaitu kuesioner dan wawancara. Responden menggunakan teknik purposive yaitu (1) aparat desa terdiri dari Kepala Desa, Sekretaris Desa, Bendahara Desa, Kepala BPD, Ketua Karang Taruna, Ketua Ulama, dan Ketua Bumdes. (2) pengelola wisata (Ketua RT dan Pengelola Wisata merangkap anggota karang taruna) dan (3) Pengunjung yang ditemui dilapangan dengan menggunakan sample simple sederhana. Lokasi penelitian berada di Kampung Penyeredan, Desa Cimanggu Kecamatan Cisalak, Kabupaten Subang Provinsi Jawa Barat. Penelitian dilakukan pada bulan April 2019

\section{HASIL DAN PEMBAHASAN}

Kondisi alam dengan segala keanekeragaman hayati dan indahnya panorama alam tersebut banyak menjanjikan potensi bila dikembangkan,dan dapat bermanfaat bagi masyarakat, daerah maupun lingkup yang lebih besar yaitu negara Indonesia.

Salah satu potensi wisata yang dapat dikembangkan dan dimanfaatkan oleh masyarakat adalah potensi wisata yang ada di Provisi Jawa Barat khususnya di Kabupaten Subang, Kecamatan Cisalak yang berada di Desa Cimanggu tepatnya di Kampung Penyeredan yang tidak kalah indahnya adalah lokasi wisata Curug Paog dan Bukit Pasir Jaka yang lokasinya berada tidak jauh dari Kantor Kepala Desa Cimanggu yang bisa ditempuh sekitar 30 menit dari Desa Cimanggu.

Hal yang menjadi daya tarik pengunjung dan yang harus di rancang mengenai perjalanan menuju ke bukit tersebut adalahjalur yang aman dan lancar yang dibutuhkan jalan yang diaspal atau di tembok sehingga pengunjung mudah mendakinya. Jalanan setapak menuju lokasi Curug Paog dan Bukit Pasir Jaka kondisinya masih alami dengan kontur yang menanjak, namun meskipun menanjak dengan melihat keindahan dan landscape persawahan dan deretan perbukitan yang ada diibawahnya mampu menghilangkan semua rasa lelah yang dibawa ketika mendaki.

Bukit Pasir Jaka merupakan tanah perbukitan yang berada di wilayah Kampung Penyeredan, Desa Cimanggu dengan ketinggian sekitar 1000 mdpl menawarkan keindahan luar biasa bila kita berhasil mencapai puncaknya, bahkan rasa capek dan lelah akan terbayar ketika kita mencapai puncak Bukit Pasir Jaka, gugusan bukit dan indahnya panorama bentangan persawahan di bawahnya serasa melambungkan rasa kita seperti di negeri awan. Pengunjung bisa menikmati semburat jinggawarna langit dipagi hari. 
Pesona wisata yang berada di Desa Cimanggu menjadi daya tarik tersendiri bagi wisatawan lokal maupun sekitar untuk datang dan berkunjung melihat keindahan alam baik Curug Paok maupun Bukit Pasir Jaka, kedua lokasi wisata letaknya berdekatan dan berada di Desa Cimanggu yang bisa ditempuh selama 30 menit untuk masing-masing lokasi. Kedua lokasi wisata ini memiliki potensi besar untuk dikembangkan. Curug Paog merupakan salah satu air terjun berundak yang sangat indah mempesona bila kita bias menikmati keindahan panorama alamnya, bila berkesempatan untuk dapat ke lokasi tersebut maka pastilah berkeinginan untuk kembali berkunjung karena keindahannya.

Menjamurnya lokasi wisata yang menawarkan sejuta keindahan alam dan didukung pengelolaan yang baik di beberapa wilayah di Indonesia saat ini tentumerupakanhalmenarik yang diburu wisatawan untuk datang dan menikmati keindahan wisata tersebut. Saat ini kondisi kedua lokasi wisata tersebut masih asli dan belum terkelola secara baik, baik dari pengelolaannya maupun wadah yang mengelola( lembaganya) juga belum ada, padahal bila melihat peta lokasi dan potensi wisata dari kedua lokasi wisata tersebut sangat memungkinkan untuk dikembangkan menjadi desa wisata, yang banyak diminati dan dikunjungi masyarakat. Tidak hanya masyarakat lokal namun juga wisatawan dari luar daerah bahkan internasional.

Atas potensi wisata tersebut maka lokasi wisata yang berada di Kampung Penyeredean, Desa Cimanggu tersebut perlu untuk dikelola dengan baik sehingga potensi dan keunggulan ekonomi masyarakat sekitar bisa berkembang, memberikan nilai tambah baik secara ekonomi maupun pemberdayaan masyarakatnya. Secara lokasi wisata dapat berkembang, makanan dan budaya khas masyarakat lokal dan cinderamata khas Subang juga bisa berkembang. Dengan berpendududuk sejumlah 3.370 orang tersebut diharapkan geliat ekonomi Desa Cimanggu terangkat melalui 2 lokasi

\section{MEWUJUDKAN TATA KELOLA LOKASI WISATA YANG BAIK}

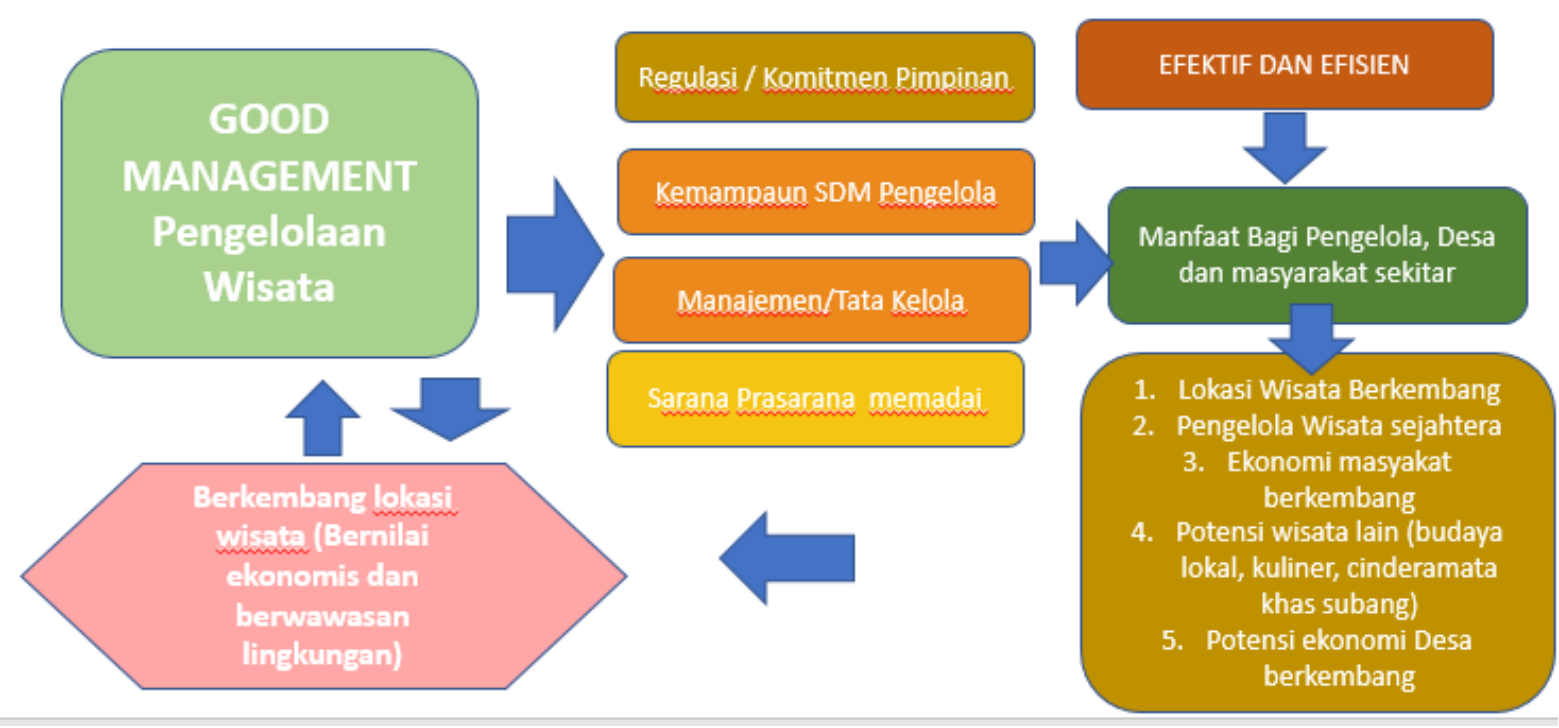

Gambar 4 . 1

Memujuckan Tata Kelola Lokasi Wsata 
Metode fenomenologi dapat dimulai dengan memperhatikan dan menelaah fokus fenomena yang hendak diteliti, yang melihat berbagai aspek subjektif dari perilaku objek. Dalam konteks penelitian ini maka yang menjadi obyek peneltian yaitu bukit pasir jaka dan curug Paog, merupakan dua destinasi wisata yang berada di Kampung Penyeradan tepat di Gunung Canggah merupakan lokasi iwsata yang sangat potensial untuk dikembangkan menjadi lokasi wisata.

Kondisi kedua lokasi wisata saat ini sangat alami meskipun menwarkan pemandangan yang indahnya tiada duanya namun kondisinya masih apa adanya, belum ada pengelolaan baik dari masyarakat lokal selaku pemilik lokasi wisata atau pengelola wisata ataupun dari pemerintah desa atau dinas terkait. Wadah dan tenpat yang menaungi pengelolaan lokasi wisatapun belum ada.

Subyek penelitian ini adalah Masyarakat lokal yang akan menjadi pengelola wisata yang terdiri dari : Desa dan Ketua Adat, yang akan mengelola lolasi wisata juga belum memiliki kemampuan dan pengetahuan yang memadai dalam mengelola lokasi wisata.

Dalam tahapan selanjutnya Peneliti melakukan penggalian data berupa bagaimana pemaknaan objek dalam memberikan arti terhadap fenomena terkait. Dari penelitian yang dilakukan ke dua obyek wisata tersebut, diketahui memiliki potensi besar untuk dikembangkan antara lain :

Curug paok

Curug Paok merupakan wisata air yang sangat indah dan destinasi ini akan lebih menarik apabila dijadikan wisata terpadu dengan Bukit Pasir Jaka. Lokasinya pun tidak terlau jauh dari Lokasi Bukit Pasir Jaka, Perjalanan dari bukit Pasir Jaka ke Curug Paok akan lebih menarik jika ditempuh dengan jalan kaki melewati lereng bukit, pesawahan, sungai-sungai kecil yang akan menambah pengalaman menarik untuk menyusurinya selain itu udara segar akan menambah serunya menyusuri Curug Paok.

Untuk bisa sampai ke lokasi Curug Paog pengunjung bisa berjalan kaki melewati jalan setapak dengan kontur yang menanjak selama kurang lebih 30-40 menit, jalur ini juga merupakan jalur pendakian ke puncak Gunung Canggah dan satu jalur pula menuju ke arah bukir pasir Jaka, hanya saja ketika sudah sampai di lokasi yang akan menjadi perluasan area parkir nanti akan jalan petunjuk arah kearah kanan untuk menuju ke Bukit Pasir Jaka dan jalan setapak ke arah kiri untuk bisa ke Curug Paog. Sumber air curug paok berasal dari aliran sungai yang melintasi bibir tebing terjal dengan keitnggian tebing rat-rata 50 s.d 70 meter

Bukit pasir jaka

Bukit pasir Jaka ini masih berada disatu hamparan dengan bukit pamoyaman yang masuk desa Kawungluwuk Tanjungsiang, sedangkan Bukit Pasir Jaka terletak di Kampung Panyeredan Desa Cimanggu Kecamatan Cisalak. Bukit Pasir Jaka menawarkan pesona berupa bentangan alam dari ketinggian 1000 mdpl.

Bukit Pasir Jaka lokasi tidak terlalu jauh dari pusat kota Kabupaten Subang dapat ditempuh sekitar 1 jam, lokasinya juga tidak terlalu Jauh dari kantor Kepala Desa Cimanggu pengunjung dapat menitipkan kendaran didekat masjid Kampung Panyeredan atau di tempat parkir pengelola wisata yang sekaligus merupakan tokoh adat di kampong penyeradan, atau didepan perumahan penduduk yang memiliki tempat untuk dipakai parker kendaraan. Untuk bisa sampai ke lokasi Bukit Pasir Jaka pengunjung bisa berjalan kaki melewati jalan setapak dengan kontur yang menanjak selama kurang lebih $30-40$ menit, jalur ini juga merupakanjalur pendakian ke puncak Gunung Canggah.

Selanjutanya penggalian data ini dilakukan dengan melakukan wawancara mendalam kepada objek atau informan dalam penelitian, juga dengan melakukan observasi langsung mengenai bagaimana objek penelitian menginterpretasikan pengalamannya kepada orang lain. Dari hasil analisa lapangan yang dilakukan melalui wawancara mendalam yang dilakukan pada responden yaitu aparat desa sebanyak 8 orang sebagai berikut : (Kepala 
Desa, Sekretaris Desa, Kepala BPD, Ketua Karang Taruna, Ketua Ulama Desa Cimanggu, Bendahara Desa Cimanggu, Ketua Bumdes), Pengelola wisata Ketua RT, Pengelola Wisata, merangkap anggota karang taruna), Pengunjung yang kita temui dilokasi diperoleh gambaran informasi sebagai berikut:

Dari hasil analisa dan pengolahan data tersebut diperoleh informasi bahwa pengelolaan kedua lokasi wisata saat ini belum efektif karena:

\section{Regulasi /Komitmen Pimpinan}

Saat ini Desa Cimanggu belum memiliki regulasi terkait dengan pengelolaan Desa Wisata untuk Curug Paok dan Bukit Pasir Jaka, sudah ada kelompok pariwisata yang dibentuk dengan melibatkan beberapa pihak antara lain Badan Pemberdayaan Masyarakat Desa, Ketua MUI Desa, BUMDesa, Karang Taruna yang didukung oleh Aparat Desa Cimanggu, namun kelompok wisata tersebut belum berjalan dengan maksimal hal ini dikarenakan beberapa hal sebagai berikut:

Kelompok Pariwisata yang ada di Desa Cimanggu, telah melibatkan beberapa tokoh masyarakat dan lembaga yang ada di desa Cimanggu namun tidak berjalan maksimal, koordinasi berjalan sendiri-sendiri, pengelolaan wisata masih dilakukan dilakukan secara swadaya oleh masyarakat yang memiliki komitmen dan tanggung jawab tinggi terhadap Desa Cimanggu.Kondisi ini tentunya akan menghambat pengelolaan wisata apabila akan dikelola dan dikembangkan secara berkelanjutan apalagi bila akan dijadikan sebagai Desa Wisata, sehingga kedepan perlu upaya keras untuk dapat mengelola wisata dengan baik, perlu penumbuhan awareness atau kesadaran bersama dari Kelompok Pariwisata ini bahwa maju dan berkembangnya Desa Wisata ini tergantung pada tanggung jawab pengelola dalam mengelola Desa Wisata.

Untuk dapat menumbuhkan awareness bagi Kelompok Wisata ini perlu dilakukan beberapa hal antara lain :

a. Legalitas pengelolaan desa wisata dapat berupa peraturan desa atau surat keputusan Kepala Desa yang memuat tentang tugas tanggung jawab dan pengelolaan Desa Wisata. Tugas dan tanggung jawab dari para pengurus ini yang anti akan dijabarkan dalam berbagai kegiatan pendukung untuk memajukan desa wisata.

b. Penumbuhan awareness tersebut sejalan dengan Pasal 10 Undang-undang No. 10 Tahun 2009 tentang Kepariwisataan yang menyatakan bahwa setiap orang dan atau masyarakat di dalam sekitar destinasi pariwisata mempunyai hak prioritas untuk menjadi pekerja, konsinyasi dan pengelolaannya.

c. Berdasarkan UU tersebut maka sudah semestinya bila pengelolaan wisata dan pemberdayaan ekonomi yang terjadi disekitar lokasi wisata tujuan utamanya adalah untuk meningkatkan ekonomi dan kesejahteraan masyarakat sekitarnya.

d. Adanya sosialiasi dan penyuluhan yang bertujuan untuk penumbuhan visi bersama dan meningkatkan pemahaman dan kemampuan pengelola wisata bahwa tujuan dari pengelolaa Desa Wisata ini tidak lain adalah untuk memajukan dan memaksimalkan sumber-sumber ekonomi dan pemberdayaan ekonomi masyarakat Desa Cimanggu.

e. Belum memiliki wadah atau lembaga yang menaungi dan melaksanakan kegiatan sehari-hari dalam mengelola lokasi wisata.

f. Lokasi wisata belum memiliki tempat tersendiri yang secara khusus dapat digunakan sebagai kantor atau base camp sebagai pusat kegiatan atau aktivitas dalam pengelolaan lokasi wisata. Selain sebagai tempat atau pusat kegiatan dalam pengelolaan wisata tempat tersebut juga dapat berfungsi sebagai kantor dan pusat informasi yang dibutuhkan oleh para pengunjung baik mengenai layanan wisata atau informasi lainya yang dibutuhkan pengunjung seputar lokasi wisata. 
Pusat layanan atau informasi ini penting agar pengunjung dapat dengan mudah mendapat layanan yang dibutuhkan serta sebagai tempat koordinasi yang memudahkan petugas atau pengelola wisata untuk memantau dan mobilisasi lokasi wisata.Pusat Informasi juga bermanfaat sebagai sarana promosi yang menjelaskan tentang keindahan alam dan keunikan dari alam yang ada di lokasi, booth photo, arena bermain, peninggalan cerita legenda, atraksi khas desa tersebut, seperti seni budaya, upacara adat, budaya lokal, bahasa lokal, makanan khas lokal dan lain-lain.

\section{Kemampuan Sumber Daya Manusia di Lokasi Desa Wisata}

Hasil analisa di lapangan yang kami lakukan dengan beberapa responden yaitu pengelola wisata, aparat desa Cimanggu dan Pengunjung diperoleh informasi sebagai berikut :

a. Kemampuan dan pengetahuan untuk mengelola lokasi wisata masih sangat terbatas, Sumber daya manusia yang berada di desa tersebut sudah siap untuk menjadikan desanya menjadi desa wisata. Namun dari segi kemampuan dan pengetahuan untuk mengelola lokasi wisata masih sangat terbatas. Sehingga perlu dilakukan berbagai pelatihan, penyuluhan dan sosialisasi dari pihak terkait agar mereka memiliki kemampuan dalam mengelola wisata dan terwujudnya desa wisata tersebut. Selama ini mereka belum mendapatkan pelatihan, penyuluhan dan pembinaandaripihak manapun.

b. Pengelolaan Lokasi wisata yang ada saat ini masih dilakaukan secara swadaya dikelola oleh Ketua RT yang sekaligus merupakan tokoh masyarakat yang dituakan di Desa Cimanggu dimana posisi tempat tinggal berdekatan dengan lokasi wisata. Selain Ketua RT, beberapa masyarakat juga membantu mengelola secara swadaya dalam bentuk berjaga di lokasi wisata secara bergiliran, penyediaan lahan parkir di pelataran tempat tinggal masyarakat dan berdagang makanan dan minum ala kadarnya sepertiindomie rebus dan anekaminumdi lokasi wisata tersebut.

c. Pegawai tetap yang secara khusus mengelola lokasi wisata belum ada, sehingga pegawai atau petugas tersebut belum mendapatkan gaji atau honor yang diterima tetap setiap bulannya, mereka hanya menerima penghasilan ala kadar dari pengunjung yang telah menggunakan tempat dan jasa sebagai lahan parkir dan penunjuk arah (local guide) bagi pengunjung dikedua lokasi baik Curug Paog maupun Bukit Pasir Jaka. Pada lokasi wisata belum dikenakan tarif untuk masuk dan mengunjungi lokasi wisata, biaya hanya untuk parkir motor dan mobil dengan besaran yang tidak ditentukan atau seihklasnya, dengan kondisi tersebut maka belum bisa diketahui berapa pendapatan dalam setiap bulannya. Sehingga sumber pembiayaan yang digunakan untuk mengelola atau mengembangkan wisata juga belum ada.

d. Berkaitan dengan kemampauan dan ketrampilan pengelola wisata dalam mengelola wisata selama ini mereka belum mendapatkan pelatihan, penyuluhan pihak manapun. Sehingga sangat diperlukan sekali informasi, ilmu, motivasi yang dapatdiberikan kepada para pengelola dan masyarakat untuk memotivasi dan mengembangkan kemampuan mereka dibidang pengelolaan lokasi wisata. Desa wisata tidak dapat terwujud apabila salah satu kelompok tidak mendukung. Keramahan, kenyamanan dan kebersihan satu desa tersebut harus digerakan sebagai komitmen untuk mewujudkan desa wisata yang memberikan kenyamanan, keamanan dan ketertarikan terhadap wisatawan yang berkunjung.

e. Belum ada peningkatan kapasitas atau pelatihan yang diikuti oleh pengelola wisata atau masyarakat sekitar, kemampuan pengelolaan wisata diperoleh secara akademis karena pengelola wisata merupakan seorang sarjana ekonomi selebihnya diperoleh dari kemampuan otodidak karena dalam kesehariannya menekuni lokasi wisata tersebut. Saat ini peran Desa Cimanggu ataupun dinas terkait dalam pengelolaan maupun pengembangan lokasi wisata juga belum muncul. 


\section{Manajemen Pengelolaan DesaWisata}

Manajemen pengelola Desa Wisata belum terwujud yang dapat diketahui dari hal-hal sebagai berikut:

a. Dalam pengelolaan lokasi wisata belum ada pencatatan yang memuat tentang cash flow pendapatan dan pengeluaran dari hasil pengelolaan wisata, dan belum dilaksanakan pelaporan terkait pengelolaan lokasi wisata yaitu Bukit Pasir Jaka dan Curug Paok.

b. Pengunjung belum dikenakan biaya masuk, biaya hanya untuk parkir motor atau mobil yang besarnya tidak ditentukan. Pengunjung yang datang ke lokasi wisata tersebut adalah wisatawan lokal dan wisatawan dari desa sekitar yang memang sudah mengetahui indahnya pemandangan di kedua lokasi wisata tersebut. Sebagain besar dari pengunjung adalah mereka adalah pengunjung yang sudah datang berkunjung ke dua kali.

c. Dari pengelolaan lokasi wisata tersebut belum diperoleh pendapatan tetap yang dapat digunakan untuk biaya operasional maupun pengembangan lokasi wisata, sehingga pelaporan dalam pengelolaan lokasi wisatapun juga belum ada. Saat ini terdapat 4 warung yang membuka usaha disana, yang berasal dari masyarakat sekitar, warung tersebut menjual makanan minuman, yang masih dikelola seadanya, belum ada warung atau tempat yang menjual makanan khas, kuliner atau yang menjual cinderamata khas Subang atau khas Cimanggu yang terkenal dengan buah nanas dan manggisnya.

d. Manajemen Operasional dan Pemeliharaan

Mengingat pengelolaan wisata saat ini masih dikelola secara seadanya, dan pendapatan yang diperoleh dari hasil pengelolaan wisata belum diadministrasikan sehingga tidak diketahui berapa besarnya pendapatan yang diterima setiap bulannya. Saat ini belum ada alokasi khusus digunakan untuk biaya operasional dalam pengelolaan lokasi wisata tersebut. Informasinya yang kami peroleh dari pegunjung dimana sebagian besar dari mereka antusias untuk datang dan berkunjung ke lokasi apalagi bila lokasi wisata sudah terkelola dengan baik dandilengkapi dengan sarana dan prasarana yang memadai maka daya tarik pengunjung untuk datang kelokasi wisata akan semakin besar.

\section{Upaya Mengelola Sarana Prasarana di Lokasi Wisata}

Salah satu indikator keberhasilan dalam pengelolaan lokasi wisata adalah apabila dalam pengelolaan lokasi wisata tersebut sudah memiliki prasarana yang digunakan atau pengunjung dapat menemukan dengan mudah beberapa fasilitas yang dibutuhkan pengunjung seperti MCK, mushola, gardu pandang, jalur pendakian dan evakuasi, spot foto dan akses jalan, area parkir serta pusat informasi.

a. Saat ini lokasi wisata belum memiliki sarana MCK yang memadai baik dilokasi wisata ataupun dibeberapa titik disepanjang lokasi, bagi pengunjung yang akan ke MCK dengan cara menumpang di dibeberapa rumah penduduk yang letaknya dekat dengan lokasi wisata.

b. Belum ada mushola yang bisa dipakai untuk sholat atau sekedar melepas lelah sehabis mendaki ke bukit pasir jaka atau curug paok, satu-satunya tempat yang dapat digunakan untuk melepas lelah dan melaksanakan sholat berada di deket warung milik pengelola wisata tersebut, yang berdekatan dengan warung dan tempat parkir.

c. Lokasi wisata belum memiliki gardu pandang, gardu pandang biasanya didirikan pada posisi yang tinggi dan mudah untuk dilihat atau dicari, gardu pandang dapat digunakan baik sebagai Pos Pemantau, memantau semua kegiatan dan mobilisasi pengunjung yang berada dilokasi wisata ataupun sekedar digunakan oleh para pengunjung untuk bisa melihat secara jelas keindahan alam yang ada dilokasi karena biasanya berada ditempat yang paling tinggi.

d. Selain itu lokasi wisata juga belum memiliki jalur pengamanan sebagai tanda atau petunjuk arah atau jalan bagi pengunjung yang hendak mendaki atau kembali dari 
pendakian ataupun kembali dari dan menuju Curug Paok. Jalur pengaman ini juga berfungsi sebagai penunjuk arah yang memudahkan pengunjung untuk secara cepat menuju titik - titik aman yang memudahkan pergerakan apabila terjadi suatu yang tidak diinginkan.

e. Akses jalan menuju lokasi wisata masih berupa jalan setapak dengan kontur yang menanjak dan berupa tanah merah dan bebatuan dimana kanan dan kirinya merupakan hutan dan tanah terjal yang menuntut kehati-hatian pengunjung saat menapaki jalan. Jalan setapak tersebut merupakan salah satu jalur pendakian ke gunung canggah, namun jalur tersebut bila hujan turun menjadi sangat becek dan licin, sehingga menyulitkan pengunjung untuk mendaki atau turun dari lokasi wisata. Kondisi ini bila tidak perlu segera dicarikan upaya agar pengunjung yang sudah antusias dan bersemangat untuk datang ke lokasi wisata bisa lanjut sampai ke lokasi puncak wisata. Selain itu kondisi jalan yang becek dan licin serta kontur menanjak juga akan menjadi kendala langkah pengunjung menuju pendakian bukit pasir jaka dan curug paok.

\section{E. KESIMPULAN}

Berdasarkan pada hasil temuan lapangan dan pembahasan tersebut diatas maka dapat diperoleh kesimpulan dan saran, bahwa pengelolaan lokasi wisata di Curug Paok dan Bukit Pasir Jaka saat ini belum efektif, dapat dilihat dari :

\section{Regulasi/Komimen Pimpinan}

Saat ini kedua lokasi wisata belum memiliki regulasi baik berupa Peraturan atau Keputusan Kepala Desa sebagai payung hukum/ legalitas pengelolaan lokasi wisata baik Curug Paok maupun Bukit Pasir Jaka. Kelompok Pariwisata yang sudah terbentuk dan melibatkan pihak-pihak terkait seperti Karang Taruna, MUI Desa, BUM Desa, dan Aparat Desa juga belum maksimal menjalankan fungsinya dalam mengelola kedua lokasi wisata tersebut.

1. Kemampuan Sumber Daya Manusia dalam Menglola Lokasi Wisata

Dari sisi SDM dalam hal ini pengelola wisata sudah siap dalam mengelola desa wisata, namun masih kurang kemampuan manajerialnya dalam mengelola kedua lokasi wisata tersebut. Hal ini dikarenakan masih kurang mendapatkan penyuluhan, pelatihan tentang tata kelola desa wisata dari pihak/instansi terkait.

2. Manajemen Pengelolaan Desa Wisata

Manajemen pengelolaan desa wisata belum berjalan dengan baik, karena :

a. Belum terbentuk kepengurusan Desa Wisata..

b. Kurangnya pelayanan bagi pengunjung lokasi wisata seperti parkir motor atau mobil.

c. Belum adanya pencatatan laporan keuangan/pendapatan pengunjung yang datang secara baik.

d. Promosi lokasi wisata yang kurang gencar di media sosial.

3. Manajemen Sarana dan Parasarana Desa Wisata

Kurangya sarana dan prasarana di lokasi wisata, seperti :

a. MCK disepanjang jalur pendakian baik menuju Curug Paok maupun Pasir Jaka belum ada

b. Mushola sebagai sarana ibadah di kedua lokasi belum ada.

c. Gardu pandang di beberapa titik baik di Curug Paok maupun di Bukit Pasir Jaka belum ada.

d. Spot foto untuk menikmati keindahahan asli wisata sudah ada tetapi masih terbatas.

e. Warung-warung kecil dan gerai yang menjajakan minuman dan makanan khas Subang belum ada. 
f. Jalur pengamanan sebagai tanda atau petunjuk arah atau jalan bagi pengunjung yang hendak mendaki atau kembali dari pendakian ataupun kembali dari dan menuju kedua lokasi wisata belum ada.

g. Akses jalan menuju kedua lokasi wisata masih belum memadai.

h. Area parkir yang tersedia masih terbatas, yaitu di pelataran milik masyarakat dan pengelola .

\section{SARAN}

1. Perlu ada regulasi sebagai payung hukum yang menaungi keberadaan lokasi wisata

2. Peningkatan kapasitas bagi SDM

3. Peningkatan Pengelolaan Lokasi Wisata dengan melaksanakan kegiatan dan program yang telah ditetapkan

4. Peningkatan Sarana Prasarana

5. Mengangkat nilai-nilai budaya dan kuliner (makanan atau minuman) sebagai ciri khas masyarakat Subang

\section{DAFTAR PUSTAKA}

Adisasmita, Rahardjo. 2011. Pengelolaan, Pendapatan \& Anggaran Daerah. Yogyakarta: Graha IImu.

A.J, Muljadi. 2009. Kepariwisataan dan Perjalanan ,Jakarta : PT. Raja Grafindo Persada.

Cahyaningrum, Dinna, 2013, Studi Komparasi Potensi Wisata wangunharja dan Desa Bunihaty Dalam Satuan Kawasan Wisata Ciater di Kabupaten Subang.

Handayaningrat, Soewarno. 2006. Pengantar Studi IImu Administrasi dan Manajemen. Jakarta: Haji Masagung.

Kuswarno, Engkus. 2009. Metodologi Penelitian Fenomenologi: Konsepsi, Pedoman dan Contoh Penelitian. Bandung : Widia Padjajaran

Marlina, Nina, dkk. 2017. Efektivitas Program Prngembangan Destinasi Pariwisata di Kabupaten Ciamis (Studi pada Objek Wisata Situ Lengkong).

Moenir, A.S. 2006. Manajemen Pelayanan Umum Di Indonesia.Bumi. Jakarta : Aksara

Moleong, Lexy. J. 2007. Metode Penelitian Kualitatif, Bandung: Remaja Rosda Karya.

Nazir, M. 2009, Bogor, Metode Penelitian, Ghalia Indonesia.

Robbins, Stephen P dan Timothy A. Judge. 2010. Perilaku Organisasi. Jakarta : Salemba Empat.

Sedarmayanti, 2006, Sumber Daya Manusia dan Produktivitas Kerja, Bandung,. Penerbit Mandar Maju.

Sugiyono, 2011, Metode Penelitian Pendidikan "pendekatan kualitatif, kuantitatif R\&D", Bandung: Alfabeta.

Susilowati, Anggi, 2014. Pengaruh Pengelolaan Pantai Terhadap Kualitas Lingkungan Di Kawasan Wisata Pantai Pondok Bali. 
Winasis, Agus dan Dody Setyawan. 2016. Efektivitas Pengembangan Desa Wisata Melalui Kelembagaan dalam Peningkatan Sumber Daya Alam (SDA).

Yuliana. 2016. Efektifitas Pengelolaan Kawasan Pariwisata Sumber Ubalan.

\section{Peraturan Perundangan}

Peraturan Pemerintah No.24 Tahun 1979 mengenai Objek wisata.

Surat Keputusan Departemen Pariwisata, Pos, dan Telekomunikasi No.KM 98/PW:102/MPPT-87 mengenai Syarat Umum Bangunan/Obyek Wisata.

\section{Internet}

www. etd.repository.ugm.ac.id, Wisata dan Kelestarian Alam, diakses tanggal 22 Oktober 2018

www. toplitas.com, Definisi lokasi Wisata dan Obyek, diakses tanggal 11 November 2018

www. wikipedia.org $\rightarrow$ Definisi lokasi wisata, diakses tanggal 11 November 2018

http://repository.upi.edu/4987/4/S_GEO_0901122_Chapter1.pdf, Lokasi Wisata, diakses tanggal 11 November 2018

www. pakarkomunikasi.com/jenis-metode-penelitian-kualitatif, diakses tanggal 12 November 2018

www.disbudpora, Data Kepariwisataan, 2012 dan 2016, diakses 10 November 2018

www.bps.go.id, Subang Dalam Angka 2017, diakses tanggal 10 November 2018

www.administrasibisnis.studentjournal.ub.ac.id > article > Pengelolaan Desa Wisata Dalam Perspektif Community Based Tourism (Studi Kasus pada Desa Wisata Gubugklakah, Kecamatan Poncokusumo, Kabupaten Malang) Dimas Kurnia Purmada, Wilopo, Luchman Hakim

https://ojs.unud.ac.id , index.php , citizen , article , view , Studi Kasus Obyek Wisata Pantai Pandawa Kuta Selatan Kabupaten Badung ). Ni Luh Made Suryani; Piers Andreas Noak, I Putu Dharmanu Yudhartha

ejournal-s1.undip.ac.id/index.php/jmelSSN(Online): 2337-3814 Profil Industri Bulu Mata Dan Rambut Palsu Dikabupaten Purbalinggavirea Stacia, Edy Yusuf Agung Gunanto 